\title{
Urgensi Pencatatan Perkawinan (Perspektif Utilities)
}

\author{
Dyah Ochtorina Susanti, Siti Nur Shoimah \\ Fakultas Hukum Universitas Jember \\ dyahochtorina@gmail.com; dyahochtorina.fh@unej.ac.id
}

\begin{abstract}
Registration of marriage is the duty of administrative legislation that aims to ensure the protection and fulfillment of human rights in the future if raised legal act which implies the legal consequences that can be proved by evidence that is perfect with an authentic act as a form of legal certainty, This research aims to find and analyze and provide an understanding of the importance of registration of marriages in the positive law of Indonesia. Results of studies using normative juridical approach to legislation, and the theory of utilities (theoretical benefit) gives an explanation that the registration of marriages performed in order to give benefit profusely for the creation of happiness for many people.
\end{abstract}

Keywords : registration of marriage, marriage, utilitis theory

\begin{abstract}
Abstrak
Pencatatan perkawinan merupakan kewajiban administratif berdasarkan peraturan perundang-undangan yang bertujuan untuk memberikan jaminan perlindungan, danuhan hak asasi manusia jika di kemudian hari timbul perbuatan hukum yang berimplikasi terjadinya akibat hukum sehingga dapat dibuktikan dengan bukti yang sempurna dengan suatu akta otentik sebagai suatu bentuk kepastian hukum. Penelitian ini bertujuan menemukan dan menganalisa serta memberikan pemahaman mengenai pentingnya pencatatan perkawinan dalam hukum positif Indonesia.. Hasil dari penelitian yang menggunakan metode yuridis normatif dengan pendekatan perundang-undangan, dan teori utilities (teori kemanfaatan) ini memberikan penjelasan bahwa pencatatan perkawinan dilakukan guna memberi kemanfaatan yang sebesar-besarnya demi terciptanya kebahagiaan bagi banyak orang.
\end{abstract}

Kata Kunci : pencatatan, perkawinan, teori utilities.

\section{Pendahuluan}

Setiap manusia memiliki hak asasi untuk melanjutkan keturunannya melalui perkawinan, yakni melaksanakan suatu perkawinan yang dilaksanakan menurut kebudayaan dan kepercayaan (agama) masing-masing. Perkawinan merupakan ikatan lahir batin antara seorang pria dengan seorang wanita sebagai suami istri dengan tujuan membentuk keluarga atau rumah tangga yang bahagia dan kekal berdasarkan Ketuhanan Yang Maha Esa, sebagaimana diatur dalam Pasal 1 Undang-Undang No. 1 Tahun 1974 tentang Perkawinan (selanjutnya disebut UU Perkawinan). Setiap orang atau pasangan yang sudah melakukan perkawinan maka terhadapnya ada ikatan kewajiban dan hak diantara 
mereka berdua dan anak-anak yang lahir dari perkawinan tersebut.

Sebelum lahirnya UU Perkawinan, mengenai ketentuan, tatacara dan sahnya suatu perkawinan bagi orang Indonesia pada umumnya didasarkan pada hukum agama dan hukum adat masing-masing. Menurut hukum adat, perkawinan adalah suatu ikatan antara seorang laki-laki dengan seorang perempuan untuk membentuk rumah tangga yang dilaksanakan secara adat dan agamanya dengan melibatkan keluarga kedua belah pihak saudara maupun kerabat (Soerjono, $1988: 55$ ).

Aturan ini kemudian dirasa sudah tidak relevan lagi dengan kebutuhan dan permasalahna - permasalahan yang timbul di zaman sekarang ini. Syarat perkawinan yang hanya dilakukan berdasarkan agama dan hukum adat, tidak menjamin adanya kepastian hukum bilamana di kemudian hari terjadi suatu peristiwa hukum atau konflik diantara kedua belah pihak. Terkait hal tersebut berarti, tidak ada bukti otentik yang dijadikan dasar untuk menyelesaikan konflik tersebut.

Setelah berlakunya UU Perkawinan, maka terjadi unifikasi hukum dalam perkawinan di Indonesia, dimana perkawinan mempunyai hubungan yang sangat erat dengan agama/kerohanian. Pengaturan hukum tentang perkawinan telah berlaku sama terhadap semua warga Negara oleh karena itu, setiap warga negara harus patuh terhadap hukum yang berlaku, termasuk terhadap UU Perkawinan yang menjadi landasan untuk menciptakan kepastian hukum, baik dari sudut hukum keluarga, harta benda, dan akibat hukum dari suatu perkawinan (K. Wantjik Saleh, 1982:3).

Pasal 2 ayat (1) UU Perkawinan menjelaskan bahwa "Perkawinan adalah sah apabila dilakukan menurut hukum masing-masing agama dan kepercayaan itu”. Ketentuan itu menggambarkan prinsip Pancasila yang pertama yaitu "Ketuhanan Yang Maha Esa”. Hal itu merupakan prinsip utama dari sahnya perkawinan dan suatu bentuk tolerasansi antar umat beragama. Berlanjut pada Pasal 2 ayat (2) UU Perkawinan menerangkan bahwa "tiaptiap perkawinan dicatat menurut peraturan perundang-undangan yang berlaku”. Pada satu sisi, keabsahan suatu perkawinan menurut UU Perkawinan adalah didasarkan pada hukum agama dan kepercayaan masingmasing.

(http://digilib.uinsby.ac.id/1720/4/Bab\% 25201.pdf\&sa=U\&ved=0ahUKEwiwzL XfqpPQAhUBpo8KHVfvCnUQFggXM Ag\&usg=AFQjCNFuJECfkHvIX7EoW 9HpQD3yousHg, diakses 5 November 2016). 
Terkait hal tersebut, berarti pencatatan perkawinan bukan menjadi penentu sah tidaknya suatu perkawinan. Hal ini yang kemudian menjadi faktor yang mengakibatkan banyak orang tidak melakukan pencatatan pada Kantor Catatan Sipil atau Kantor Urusan Agama (KUA) bagi orang muslim. Pada sisi lain, ketentuan ini merupakan suatu kesatuan yang tidak dapat dipilih keberlakuannya. Pada saat hanya memenuhi salah satu ketentuan saja, maka peristiwa perkawinan tersebut belum memenuhi unsur hukum yang ditentukan oleh undang-undang. Hal tersebut berarti, apabila ada suatu sengketa antara suami istri yang perkawinannya tidak dicatatkan, maka salah satu pihak yang bersengketa tidak dapat melakukan penuntutan.

Salah satu kasus mengenai perkawinan yang tidak dicatat yaitu kasus Machica Mochtar dalam Putusan Mahkamah Konstitusi Nomor 46/PUUVIII/2010 yang isinya permohon pengesahan anak bernama Aisyah Mochtar alias Machica sebagai anak sah dari Bapak Moerdiono. Berdasarkan Undang-Undang Perkawinan No.1 Tahun 1974, anak sah adalah anak yang lahir dalam perkawinan yang sah. Perkawinan sah adalah perkawinan yang dilakukan menurut ajaran agama dan kepercayaan serta dicatatkan pada
Kantor Urusan Agama (Bagi yang beragama Islam), dan Catatan Sipil bagi yang beragama non Islam. Machica dalam hal ini termasuk orang yang cukup beruntung walaupun perjuangan untuk mendapatkan pengakuan anaknya sebagai anak sah ditempuh dengan sedemikian rupa.

Persoalannya adalah di dalam kehidupan nyata banyak sekali anakanak yang tidak mendapat pengakuan dari ayah biologisnya karena perkawinan antara ibu-bapaknya dilakukan tanpa melalui prosedur pencatatan, atau lazim dalam masyarakat disebut sebagai pernikahan siri. Akibatnya, anak tidak memiliki akta lahir, padahal akta lahir sangat penting sebagai bukti otentik yang menjamin kepastian hukum. Selain itu, apabila ada kekerasan dalam rumah tangga atau hak istri tidak dipenuhi oleh suami, istri tidak dapat mengajukan tuntutan karena status perkawinannya tidak sah dimata hukum, sehingga negara tidak dapat memberikan perlindungan hukum untuk menjamin hak - haknya. (Hasil pengamatan penulis, Kab Jember 2016)

Berdasarkan penjelasan di atas, dapat ditemukan bahwa pencatatan perkawinan bukan persoalan sepele, karena hal ini berkaitan dengan keberlangsungan rumah tangga khusunya berkaitan dengan kepentingan 
sang anak. Belum adanya pemahaman secara mendalam mengenai pencatatan perkawinan membuat masyarakat terutama di daerah pelosok daerah kerap melakukan pernikahan sirri yang biasanya berujung perceraian. Terkait dengan hal ini, terdapat sebuah permasalahan yang menjadi tema sentral dari tulisan ini, yaitu: "Apakah urgensi dari pencatatan perkawinan?" Terkait jawaban tersebut maka pertanyaan tersebut bisa dijawab dengan menggunakan Teori Utilitis, yakni suatu cara untuk menganalisa permasalahan, mencari jawaban dilihat dari manfaat yang ditimbulkan bagi kepentingan orang banyak, sehingga harus dibuktikan pentingnya pencatatan perkawinan guna memberikan kemanfaatan yang sebesarbesarnya untuk banyak orang.

\section{Metode Penelitian}

Jenis Penelitian ini merupakan penelitian hukum normatif (normatif legal research) untuk menguraikan urgensi pencatatan perkawinan. Penelitian normatif seringkali disebut sebagai penelitian doktrinal, yaitu: penelitian yang objek kajiannya adalah dokumen peraturan perundangundangan dan bahan pustaka. (Soejono dan Abdurrahman, 2003 : 56). Senada dengan pendapat Soerjono dan Abdurrahman, Dyah Ochtorina Susanti dan A'an Efendi menegaskan penelitian hukum doktrinal adalah penelitian yang bersifat sistematis mengenai aturan hukum yang mengatur bidang hukum tertentu, menganalisis hubungan antara aturan hukum yang satu dengan yang lalin, menjelaskan bagian-bagian yang sulit untuk dipahami dari suatu aturan hukum tertentu, bahkan mungkin juga mencakup prediksi perkembangan suatu aturan hukum tertentu pada masa mendatang. (Dyah Ochtorina Susanti dan A'an Efendi, 2014:11)

Adapun pendekatan yang relevan digunakan dalam penelitian ini adalah pendekatan perundanng-undangan dan pendekatan konsep. Pedekatan Perundang-undangan dilakukan dengan menelaah semua undang-undang dan regulasi yang bersangkut paut dengan isu hukum yang diketengahkan. (Peter Mahmud Marzuki, 2005:93). Terkait penelitian iini pendekatan perundangundangan digunakan untuk menelaah peraturan perundang-undangan yang mengatur mengenai pencatatan perkawinan. Adapun pendekatan konseptual dilakukan pada saat peneliti tidak beranjak dari aturan hukum yang ada, dan hal tersebut dilakukan karena memang belum ada atau tidak ada aturan hukum untuk masalah yang dihadapi. Saat menggunakan pendekatan konseptual peneliti perlu merujuk 
prinsip-prinsip hukum yang dapat ditemukan dalam pandangan para sarjana hukum ataupun doktrin hukum. (Dyah Ochtorina Susanti dan A'an Efendi, 2014:115)

Selanjutnya bahan-bahan hukum yang digunakan untuk dapat menemukan jawaban atas isu hukum mengenai urgensi pencatatan perkawinan mencakup : Pertama, Bahan Hukum Primer yaitu bahan hukum yag memiliki otoritas (Authority), artinya bersifat mengikat (Dyah Octorina Susanti, 2014: 52), yang terdiri atas : 1) Undang-Undang Nomor 1 Tahun 1974 Tentang Perkawinan. Tahun 1974 Tentang Perkawinan; 2) Peraturan Pemerintah No. 9 Tahun 1975 Tentang Pelaksanaan Undang-Undang No. 1 Tahun 1974 Tentang Perkawinan; 3) Instruksi Presiden No. 1 Tahun 1991 Tentang Penyebarluasan Kompilasi Hukum Islam Bahan hukum sekunder bahan yang memnjelskan bahan hukum primer. Seperti: hasil penelitian, jurnal ilmiah, hasil seminar atau penemuan ilmiah lainnya, bahkan menurut Ronny Hanitijo Soemitro dalam Dyah Ochtorina Susanti, dokumen pribadi atau pendapat dari kalangan pakar hukum sekunder ini sepanjang relevan dengan objek telaah penelitian hukum berupa jurnal ini (Dyah Ochtorina Susanti, 2014: 22).
Kedua, Bahan hukum tersier, yaitu bahan hukum penunjang yang memberi petunjuk dan penjelasan terhadap bahan hukum primer dan bahan hukum sekunder, seperti kamus hukum dan kamus bahasa Indonesia (Soerjono \& Sri, 2001:14-15).

Sedangkan pengumpulan dan penelusuran bahan hukum dilakukan dengan menggunakan metode kepustakaan sistematis, yaitu penelusuran dokumen terkait dengan urgensi pencatatan perkawinan dan teori utilitis. Berbagai informasi yang di dapat dari penelitian ini kemudian akan dianalisa dengan menggunakan metode analisis isi (content analysis). (Valerina J1. Kriekhoff, 2002:27) baik dalam menganalisa urgensi pencatatan perkawinan kaitannya dengan kemanfaatan (utilitis).

\section{Hasil Dan Pembahasan}

\section{Urgensi Pencatatan Perkawinan (Perspektif Utilities)}

Pada bagian hasil dan pembahasan ini, penulis bertolak ukur pada kasus Machica Mochtar yang pada akhirnya diputuskan Mahkamah Konstitusi pada Putusan Mahkamah Konstitusi Nomor 46/PUU-VIII/2010. Pada kasus tersebut, diawali tanggal 20 Desember 1993, di Jakarta telah berlangsung pernikahan antara Hj. Aisyah Moctar alias Machica 
binti H.Moctar Ibrahim dengan seorang laki-laki bernama Drs. Moerdiono, dengan wali nikah almarhum H. Moctar Ibrahim, disaksikan oleh 2 orang saksi masing-masing bernama almarhum $\mathrm{KH}$. M. Yusuf Usman dan Risman dengan mahar berupa seperangkat alat shalat, uang 2.000 Riyal (mata uang Arab), satu set perhiasan emas dibayar tunai. Moerdiono seorang suami yang sudah beristri menikah lagi dengan Machica dengan akad nikah secara Islam tetapi tidak dihadapan Pegawai Pencatat Nikah/Kantor Urusan Agama di daerah Kecamatan yang berwenang sehingga tidak dicatat dalam buku akta nikah dan tidak memiliki kutipan akta nikah. Pada perkawinan tersebut lahirlah seorang anak laki-laki bernama Muhammad Iqbal Ramadhan bin Moerdiono. (Lihat Putusan MK No. 46/PUU-VIII/2010)

Pada hari Senin, tanggal 14 Juni 2010, Machica Mochtar mengajukan permohonan uji materiil (judicial review) Undang-Undang No. 1 Tahun 1974 Tentang Perkawinan. Pada kasus ini, Machica Moctar sebagai ibu kandung dari Muhammad Iqbal menuntut pengakuan dari Moerdiono, terhadap anak yang lahir dari hasil pernikahan siri mereka dengan permohonan uji materiil terhadap Pasal 2 ayat (2) dan Pasal 43 ayat (1) UU Perkawinan. Pada hari Senin, 13
Februari 2012, keluarlah Keputusan Mahkamah Konstitusi mengenai status anak diluar perkawinan.Anak luar kawin menurut Pasal 43 ayat (1) UU Perkawinan menyebutkan bahwa anak luar kawin adalah anak yang dilahirkan diluar perkawinan, hanya mempunyai hubungan perdata dengan ibunya dan keluarga ibunya.

Kasus Machica Mochtar diatas merupakan gambaran bahwa tidak adanya bukti yang menjelaskan adanya suatu perkawinan berupa akta nikah, maka tidak ada pula kepastian hukum di dalam perkawinan tersebut. Sehingga, suami yang melakukan perkawinan tanpa dicatatkan dapat untuk tidak mengakui anak dari istrinya itu. Hal ini tentu berdampak pada psikologis dan hak seorang anak. Hak untuk memperoleh perlindungan hukum, pendidikan, ataupun kesejahteraan sosial.

Terkait makna perkawinan, perlu dipahami bahwa perkawinan adalah ikatan lahir batin antara seorang pria dan seorang wanita sebagai suami istri dengan tujuan membentuk keluarga atau rumah tangga yang bahagia dan kekal berdasarkan Ketuhanan Yang Maha Esa (Lihat Pasal 1 UU Perkawinan). Perkawinan merupakan hal yang penting dalam kehidupan setiap manusia.Sesuatu yang penting biasanya akan diabadikan 
melalui tulisan atau gambar sebagai bukti atas diadakannya peristiwa tersebut. Salah satu cara membuktikan adanya perkawinan yaitu melalui pencatatan.

Pencatatan Perkawinan adalah kegiatan menulis yang dilakukan oleh seseorang mengenai suatu peristiwa yang terjadi. Pencatatan perkawinan sangat penting, sebab buku nikah yang diperoleh merupakan bukti otentik tentang keabsahan pernikahan itu, baik secara agama maupun negara. Dengan buku nikah, mereka (suami-isteri) dapat membuktikan pula keturunan sah yang dihasilkan dari perkawinan tersebut dan memperoleh hak-haknya sebagai ahli waris (Abdul Manan, 2006: xx). Fakta empiris, perkawinan di Indonesia ada yang tercatat dan ada yang tidak tercatat.

Menurut Jaih Mubarok, pada umumnya yang dimaksud dengan perkawinan tidak tercatat adalah perkawinan yang tidak dicatat oleh Pegawai Pencatat Nikah (selanjutnya disebut PPN) atau perkawinan yang dilakukan oleh orang-orang Islam Indonesia, memenuhi baik rukun-rukun maupun syarat-syarat perkawinan, dan didaftarkan pada pejabat pencatat nikah. Sebaliknya, perkawinan tercatat adalah perkawinan yang tidak berada di bawah pengawasan PPN, dianggap sah secara agama tetapi tidak mempunyai kekuatan hukum karena tidak memiliki buktibukti perkawinan yang sah menurut peraturan perundang-undangan yang berlaku (Jaih Mubarok, 2005: 87).

Menurut Undang-Undang No. 1 Tahun 1974 Tentang Perkawinan, sahnya perkawinan disandarkan kepada hukum agama masing-masing (Pasal 2 ayat(1)). Ketentuan pasal ini bermakna bahwa suatu perkawinan yang telah dilakukan menurut tata cara dan aturan serta kebiasaan agamanya masingmasing, maka perkawinan tersebut adalah

sah. (http://digilib.uinsby.ac.id/1720/4/Bab\% 25201.pdf\&sa=U\&ved=0ahUKEwiwzL XfqpPQAhUBpo8KHVfvCnUQFggXM Ag\&usg=AFQjCNFuJECfkHvIX7EoW 9HpQD3yousHg, diakses 5 November 2016). Pasal 2 ayat (2) UU Perkawinan menyebutkan bahwa: "Tiap-tiap perkawinan dicatat menurut peraturan perundang-undangan yang berlaku." Pasal ini mempunyai makna, sahnya perkawinan disandarkan kepada hukum agama masing-masing, namun demikian suatu perkawinan belum dapat diakui secara hukum positif yang berlaku di Indonesia, apabila perkawinan tersebut tidak dicatat sesuai dengan ketentuan peraturan perundang-undangan

Islam sendiri memerintahkan agar pernikahan dilakukan secara terbuka dan tidak ditutup-tutupi. Pada hukum Islam, 
setiap transaksi mu'amalah yang tidak secara tunai diwajibkan untuk dicatat. Hal tersebut dapat ditemukan pada Firman Allah SWT (Jamaluddin dan Nanda Amalia, 2016: 37). yang tercantum dalam Surat Al-Baqarah ayat 28 yang terjemahnya sebagai berikut :

$\begin{array}{ll}\text { "Hai orang-orang } & \text { yang } \\ \text { beriman,apabila } & \text { kamu }\end{array}$

bermu'amalah tidak secara tunai untuk waktu yang tidak ditentukan, hendaklah kamu menuliskannya. Dan hendaklah seorang penulis di antara kau menuliskannya dengan benar”.

Berdasarkan ayat tersebut dapat dipahami, bahwa pencatatan merupakan alat bukti tertulis. Meskipun perintah pencatatan pada ayat tersebut adalah terkait dengan perikatan yang bersifat umum, namum berlaku juga pada masalah pernikahan. Apabila perikatan (akad) muamalah saja dianjurkan agar dicatat untuk dijadikan alat bukti, tentunya akad nikah sebagai perikatan yang kokoh dan langgeng (mitsaaqan ghalizhan) mestinya seruannya lebih dari itu (Jamaluddin dan Nanda Amalia, 2016: 37).

Instruksi Presiden No. 1 Tahun 1991 Tentang Penyebarluasan Kompilasi Hukum Islam (selanjutnya disebut KHI) juga mengatur mengenai Pencatatan perkawinan tercantum di dalam Pasal 5 ayat (1): “agar terjamin ketertiban perkawinan bagi masyarakat Islam setiap perkawinan harus dicatat", dilanjutkan ayat (2): "Pencatatan perkawinan tersebut pada ayat (1), dilakukan oleh Pegawai Pencatat Nikah sebagaimana yang diatur dalam Undangundang No.22 Tahun1946 jo Undangundang No. 32 Tahun 1954".

Terkait itu, istilah "harus dicatat" dalam Pasal 5 Ayat (1) KHI juga hanya bertujuan untuk menjamin ketertiban perkawinan bagi masyarakat Islam semata. Berdasarkan hal tersebut, sudah seharusnya umat Islam Indonesia harus menyadari bahwa pencatatan suatu perkawinan merupakan aspek yang sangat penting karena merupakan ajaran agama yang langsung sebagai perintah Allah SWT, dan telah diperjuangkan oleh umat Islam Indonesia sebagai hukum positif sehingga mempunyai daya mengikat dan memaksa untuk dipatuhi dan dijalankan oleh seluruh umat Islam (Jamaluddin dan Nanda Amalia, 2016: 37).

Pada Peraturan Pemerintah No. 9 Tahun 1975 Tentang Pelaksanaan UndangUndang Nomor 1 Tahun 1974 Tentang Perkawinan (selanjutnya disebut PP No. 9 Tahun 1975), dalam Pasal 1 ayat (1) dijelaskan bahwa :

"Pencatatan perkawinan dari mereka yang melangsungkan perkawinannya 
menurut agama Islam, dilakukan oleh Pegawai Pencatat sebagaimana dimaksud dalam Undang-undang Nomor 32 Tahun 1954 tentang Pencatatan Nikah, Talak dan Rujuk"

Pada ayat (2) dijelaskan bahwa :

"Pencatatan perkawinan dari mereka yang melangsungkan perkawinannya menurut agamanya dan kepercayaannya itu selain agama Islam, dilakukan oleh Pegawai Pencatat Perkawinan pada kantor catatan sipil sebagaimana dimaksud dalam berbagai perundangundangan mengenai pencatatan perkawinan".

Menurut penulis, ketentuanketentuan di atas sudah jelas bahwa Undang-Undang telah memerintahkan untuk mencatat setiap perkawinan. Menjadi makna yang ambigu di dalam bahasa hukum, apabila pencatatan perkawinan wajib dilakukan, maka sudah seharusnya aturan mengenai kewajiban mencatat perkawinan tersebut dilengkapi dengan sanksi bagi setiap pelanggarnya. Terkait penjatuhan sanksi dan/atau pemberian denda bagi pihak yang tidak melakukan pencatatan perkawinan ini, hukum positif di Indonesia tidak mengaturnya.

Pada tataran demikian, menurut penulis terjadi kekosongan hukum yang berakibat tidak tercapainya ketertiban dan kepastian hukum perkawinan yang dilakukan oleh para pihak. Implikasi yang lebih besar dari tidak tercatatnya perkawinan ini, adalah tidak terdeteksinya berapa kali seorang lakilaki melakukan perkawinan, dan pada saat perkawinan tersebut menghasilkan anak atau anak-anak, maka dapat terjadi kemungkinan anak-anak (yang saling tidak mengetahui bahwa ayah mereka adalah sama), melakukan perkawinan di kemudian hari. Sebagai contoh, pernah terjadi di Pengadilan Agama Sidoarjo, putusan hakim pengadilan agama yang membatalkan perkawinan dari para pihak karena diketahui (setelah terjadi perkawinan dan mempunyai anak) suami dan istri tersebut adalah kakak adik satu ayah lain ibu. (Lihat Rama Stia Prasaja, 2014 : 5)

Berdasarkan sensus yang dilakukan oleh Lembaga Swadaya Masyarakat (LSM) Pemberdayaan Perempuan Kepala Keluarga (Pekka) pada tahun 2012, 25 persen masyarakat di Indonesia melakukan perkawinan siri dan secara adat, dan mereka tidak melakukan pencatatat perkawinan (https://m.merdeka.com/peristiwa/25persen-masyarakat-indonesiamelakukan-nikah-siri.html, diakses 08 November 2016).

Tidak dapat dipungkiri beberapa daerah di Indonesia para penduduk masih sering tidak mencatatkan 
perkawinan dengan berbagai faktor yang menjadi alasan, salah satunya di Desa Kalisat, Kecamatan Rembang, Kabupaten Pasuruan yang di juluki “Kampung Nikah Siri”. Fenomena nikah siri sendiri sudah melekat di wilayah Rembang sejak bertahun-tahun sampai saat ini. Pihak lelaki yang melakukan pernikahan siri tidak hanya dari warga lokal, tetapi juga warga asing, contohnya Arab Saudi. Usia penikahanpun tidak bertahan lama. (http://radarbromo.jawapos.com/read201 6/05/30/1291/nih-dia-kampung-nikahsiri-di-rembang-kabupaten-pasuruan/1, artikel oleh Zubaidillah, 30 Mei 2016)

Hal ini menunjukkan bahwa pencatatan perkawinan merupakan sesuatu hal yang penting dan tidak dapat dikesampingkan karena hal ini menyangkut kepentingan orang banyak. Pada tataran ini, penulis berasumsi bahwa pencatatan bukan merupakan persyaratan administratif semata, akan tetapi merupakan upaya untuk memberikan kemanfaatan untuk semua pihak agar tercipta suatu keadilan yang tidak hanya menguntungkan salah satu pihak saja.

Terkait mengenai kemanfaatan, maka penulis meninjau pentingnya pencatatan perkawinan dari sisi teori utilitis. Penganut aliran utilitis menganggap bahwa tujuan hukum sernata-mata untuk memberikan kemanfaatan atau kebahagiaan yang sebesar-besarnya bagi sebanyakbanyaknya warga masyarakat. Penanganannya di dasarkan pada filsafat sosial bahwa setiap warga negara masyarakat mencari kebahagiaan dan hukum merupakan alatnya (Ahmad Ali, 2009: 272).

Pakar-pakar penganut aliran utilistis ini adalah Jeremy Bentham, yang dikenal sebagai the father of legal utilitarianism (Ahmad Ali, 2009: 272). Selain Bentham, masih dikenal James Mill dan Jhon Stuart Mill.Menurut Bentham, hukum bertujuan untuk mewujudkan apa yang bermanfaat atau yang sesuai dengan kepentingan orang banyak, pernyataannya yang terkenal adalah the Greatest Happiness for the Greatest Number, artinya kebahagiaan yang terbesar untuk jumlah yang terbanyak. Bentham dalam Nurhadi menaruh perhatian besar terhadap penerapan asas manfaat dalam peraturan perundang-undangan sehingga banyak berkarya tentang pokok ini, di antaranya The Theory of Legislation (Nurhadi, 2006:1).

Merujuk pendapat Bentham ini, Undang-Undang telah menjamin kepastian hukum kepada masyarakat, sebagaimana dimaksud dalam UU Perkawinan, PP No. 9 Tahun 1975, dan 
KHI, bertujuan untuk tertib administrasi perkawinan, memberikan kepastian, dan manfaat bagi masyarakat berupa perlindungan terhadap status hukum suami, istri maupun anak, dan memberikan jaminan serta perlindungan terhadap hak-hak tertentu yang timbul karena perkawinan seperti hak waris, hak untuk memperoleh akta kelahiran, dan lain-lain.

Pemikiran Bentham ini kemudian dikembangkan oleh Jhon Stuart Milldengan beberapa modifikasi. $\mathrm{K}$. Bertens mencatat 2 (dua) pendapat penting dari Mill dalam dalam upaya perumusan ulang terhadap utilitarianisme. Pertama, ia mengkritik pandangan Bentham bahwa kesenangan dan kebahagiaan harus diukur secara kuantitatif. Sebaliknya, ia berpendapat bahwa kualitasnya perlu dipertimbangkan juga, karena ada kesenangan yang lebih tinggi mutunya dan ada yang lebih rendah. Kedua, kebahagiaan yang menjadi norma etis adalah kebahagiaan semua orang yang terlibat dalam suatu kejadian, bukan kebahagiaan satu orang saja yang barangkali bertindak sebagai pelaku utama. Raja dan bawahan dalam hal ini harus diperlakukan sama. Kebahagiaan satu orang tidak pernah boleh dianggap lebih penting daripada kebahagiaan orang lain. Menurut perkataan Mill sendiri : "Everybody to count for one, nobody to count for more than one". Terkait demikian, suatu perbuatan dinilai baik manakala kebahagiaan melebihi ketidakbahagiaan, di mana kebahagiaan semua orang yang terlibat dihitung dengan cara yang sama (Richard Schoch, 2009: 249-50).

Terkait pendapat Mill ini, suatu peraturan perundang-undangan yang dibuat tidak boleh mementingkan atau menguntungkan salah satu pihak saja. Begitupun dengan aturan mengenai pencatatan perkawinan. Pencatatan perkawinan diatur dan dibuat tidak hanya mementingkan kepentingan pihak suami, tetapi juga kepentingan istri dan anak dalam hal memberikan perlindungan hukum, memenuhi hakhak suami, istri, dan anak, serta memberikan kebahagiaan yang sebesarbesarnya untuk semua anggota keluarga. Hal ini jelas bahwa apabila perkawinan melalui proses pencatatan, maka semua pihak akan menerima hak-hak yang seharusnya didapat.

Perkawinan yang tidak dicatatkan akan menimbulkan kerugian bagi pihakpihak tertentu. Akibat yang ditimbulkan perihal tidak dicatatnya perkawinan diantaranya: Pertama, pasangan suami istri tersebut tidak memiliki bukti otentik bahwa mereka telah melaksanakan suatu perkawinan yang sah. Akibatnya, dilihat 
dari aspek yuridis, perkawinan tersebut tidak diakui pemerintah, sehingga tidak mempunyai kekuatan hukum (no legal force). Terkait itu, perkawinan tersebut tidak dilindungi oleh hukum, dan bahkan dianggap tidak pernah ada (Jamaluddin dan Nanda Amalia, 2016: 38). Negara tidak dapat memberikan perlindungan mengenai status perkawinan, harta gono-gini, waris, dan hak-hak lain yang timbul dari sebuah perkawinan, karena untuk membuktikan adanya hak istri harus dibuktikan terlebih dahulu adanya perkawinan antara istri dengan suaminya.

Kedua, pada saat terjadi wanprestasi terhadap janji perkawinan, maka peluang untuk putusnya perkawinan akan terbuka secara bebas sesuka hati suami atau istri, tanpa adanya akibat hukum apapun, sehingga hampir semua kasus berdampak pada wanita yang kemudian akan berakibat buruk kepada anak-anaknya (Anshary, 2010:30). Dampak yang ditimbulkan diantaranya: adanya penelantaran istri dan anak, kekerasan dalam rumah tangga, fenomena kawin kontrak, fenomena istri simpanan (wanita idaman lain), termasuk praktik poligami yang tidak resmi.

Menurut penulis, point Ketiga dari akibat perkawinan yang tidak dicatat adalah, terjadi pelanggran terhadap tujuan hukum Islam (Maqashid al syari'ah atau maqhasidus-syar'i) yang salah satu tujuannya adalah menjaga keturunan (jiwa). Pada saat perkawinan tidak dicatat dan terjadi didalam beberapa perkwainan yang dilakukan oleh seorang laki-laki, maka dapat dikuatirkan bahwa keturunan-keturunan (anak-anak) dai perkawinan pertama, kedua dan seterusnya, dikemudian hari akan melakukan perkawinan tanpa mengetahui bahwa ayah mereka sama.

M. Quraish Shihab juga mengemukakan pendapat bahwa perkawinan yang tidak tercatat merupakan salah satu bentuk pelecehan terhadap perempuan karena dapat menghilangkan hak-hak kaum perempuan. (M. Quraish Shihab, 2006:216).

Bagi pemeluk agama Islam, jika tidak dapat membuktikan terjadinya perkawinan dengan akta nikah, dapat mengajukan permohonan itsbat nikah (penetapan/pengesahan nikah) kepada Pengadilan Agama sebagaimana telah diatur dalam Pasal 7 KHI. Pengajuan itbat nikah dengan alasan lain (bukan dalam rangka perceraian) hanya dimungkinkan, jika sebelumnya sudah memiliki Akta Nikah dari Pejabat berwenang.

Keempat, anak-anak yang dilahirkan dari perkawinan yang tidak 
dicatat, akan mengalami kesulitan dalam mengurus akta kelahiran. Hal tersebut didasarkan bahwa salah satu persyaratan mengurus akta kelahiran adalah akta perkawinan kedua orang tuanya (buku nikah). Pada tataran berikutnya, anak yang tidak memiliki akta lahir, akan kesulitan dalam mengurus pendaftaran sekolah, mengurus tunjangan keluarga, dan lain sebagainya. Pada hukum positif indonesia, anak yang lahir dari perkawinan yang tidak dicatat seringkali mengalami "kerugian", terutama dalam bidang hak waris (Lihat Kasus Machicha Mochtar). Salah satu bentuk kerugian yang di derita anak yang lahir dari perkawinan yang tidak dicatat adalah akan kesulitan mengurus akta kelahiran, dan pada umumnya nama orang tua yang tercantum pada akta kelahiran adalah nama ibunya. Secara psikologis, hal ini akan membawa dampak pada sisi psikologis anak, karena di masyarakat pada saat menemukan akta lahir anak yang hanya mencantumkan nama ibunya maka masyarakat akan berasumsi bahwa anak yang bersangkutan adalah anak yang lahir diluar perkawinan. Anak akan bertanya - tanya mengenai statusnya dalam keluarga atau status perkawinan kedua orang tuanya. Hal ini jelas bertentangan dengan prinsip teori utilitis bahwa manusia itu akan berbuat dengan cara sedemikian rupa untuk memperoleh kenikmatan yang sebesar-besarnya dan menekan serendah-rendahnya penderitaan (Edwin M. Schur, 1968: 33).

Kenikmatan dan penderitaan, tentu ada tolak ukur yang digunakan sebagai acuan dalam menentukan apa makna dari kenikmatan dan penderitaan itu sendiri. Tolak ukur kenikmatan yaitu kebahagiaan dalam jangka waktu panjang. Kenikmatan merupakan suatu akibat baik dimana setiap tindakan manusia yang dilakukan dengan kebaikan maka akan menghasilkan akibat-akibat baik pula. Contoh: suami atau istri yang hidup terlama mewarisi seluruh harta peninggalan anaknya yang meninggal tanpa meninggalkan keturunan suami atau istri, saudara lakilaki atau perempuan. Hal ini menunjukkan bahwa perkawinan yang dicatatkan tidak memutus hak seseorang untuk menjadi ahli waris bahkan hingga seumur hidup.

Ukuran Penderitaan yaitu pemutusan atau peniadaan suatu hak seseorang. Penderitaan merupakan suatu akibat buruk karena tidak sesuai dengan aturan yang berlaku, dimana setiap tindakan manusia yang dilakukan dengan keburukan maka akan menghasilkan akibat-akibat yang buruk pula. Contoh: Seorang lelaki dan wanita yang melakukan perkawinan tanpa 
melalui proses pencatatan, padahal lelaki tersebut telah beristri dengan perkawinan yang dicatatkan, maka pada saat suami tersebut meninggal, istri pertama akan menutup hak waris dari istri yang kedua. Terkait hal tersebut berarti, perkawinan yang tidak dicatatkan akan memutus hak seseorang untuk menjadi ahli waris, sehingga yang timbul hanyalah kerugian bagi si istri.

Melihat urgensi pencatatan perkawinan yang telah dijabarkan diatas, penulis berpendapat bahwa kurangnya kesadaran dan kepahaman masyarakat mengenai pentingnya pencatatan perkawinan menyebabkan pernikahan siri menjadi alat untuk mengikat hubungan antara seorang lelaki dan perempuan secara sah menurut agama. Tingkat pendidikan yang rendah serta kultur budaya yang berdampak besar terhadap gaya hidup dalam masyarakat juga menjadi faktor tidak dicatatkannya perkawinan, terutama di daerah pedalaman. Mereka tidak memikirkan resiko yang akan ditimbulkan dikemudian hari yang bisa saja berdampak pada anak serta keturunannya.

Apabila masyarakat melaksanakan perkawinan menurut ketentuan undangundang yang berlaku, maka tujuan perkawinan untuk memperoleh ketenangan, kesenangan, kenyamanan, ketentraman lahir dan batin untuk selama-lamanya dalam kehidupan berumah tangga akan terwujud, dan pada akhirnya menciptakan sebuah keluarga yang bahagia.

\section{Simpulan}

Pencatatan Perkawinan merupakan sesuatu yang urgent di zaman sekarang ini. Banyaknya kasus penelantaran istri dan anak, perceraian, pernikahan kontrak, salah satunya disebabkan karena tidak dicatatkannya perkawinan. Mengatasi hal tersebut, pemerintah telah memberikan payung hukum yang terdapat dalam Pasal 2 ayat (2) UndangUndang No. 1 Tahun 1974 Tentang Perkawinan, PP No. 9 Tahun 1975 Tentang Pelaksanaan UU No. 1 Tahun 1974 Tentang Perkawinan, Undangundang No.22 Tahun 1946 jo UndangUndang No. 32 Tahun 1954 Tentang Pencatatan Nikah Talak, dan Rujuk. Kompilasi Hukum Islam, sebagai upaya perlindungan dari negara terhadap masyarakat. Manfaat yang timbul karena adanya pencatatan perkawinan, diantaranya: 1) Terjamin kepastian hukum status suami atau istri serta anakanak yang lahir dari perkawinan tersebut; 2) Terjamin kelangsungan (proses) pengurusan akta kelahiran bagi anak, dengan mencantumkan nama kedua orang tua secara lengkap; 3) 
Terjamin hak waris dari suami atau istri yang hidup terlama serta anak-anak yang lahir dari perkawinan tersebut.

Terkait hal ini, saran yang dapat disampaikan pada kesempatan ini ialah diharapkan kepada pemerintah untuk menghapuskan pungli terkait biaya pencatatan perkawinan di Kantor Urusan Agama, dan persingkat waktu proses mencatatkan perkawinan sehingga akan memudahkan orang-orang yang akan melakukan perkawinan dan/atau melakukan pencatatan perkawinan. Sedangkan kepada masyarakat, harus paham bahwa pencatatatan perkawinan mampu memberikan perlindungan dan kepastian hukum bagi para pihak yang terkait di dalam perkawinan.

\section{Daftar Pustaka}

\section{Buku}

Abdul Mannan. 2006. Aneka Masalah Hukum Perdata Islam di Indonesia. Jakarta: Kencana.

Ahmad Ali. 2009. Menguak Teori Hukum (Legal Theory) dan Teori Peradilan (Judicial Prudence) termasuk lnterpretasi UndangUndang (Legal Prudence). Jakarta: Penerbit kencana Jakarta. Vol. 1 Pemahaman awal.

Ahmad Rofiq. 2003. Hukum Islam di Indonesia. Jakarta: PT Raja Grafindo Persada.

Dyah Ochtorina Susanti dan A'an Efendi. 2014. Penelitian Hukum (Legal Research). Jakarta: Sinar Grafika.
Edwin M. Schur, 1968. Law and Society, A Sociological View. New York: Random House.

Jaih Mubarok. 2005. Modernisasi Hukum Perkawinan di Indonesia. Bandung: Pustaka Bani Quraisyi.

Jamaluddin \& Nanda Amalia. 2016. Buku Ajar: Hukum Perkawinan. Lhokseumawe: Unimal Press.

K. Wantjik Saleh. 1982. Hukum Perkawinan Indonesia. Jakarta Timur: Ghalia Indonesia.

M. Quraish Shihab. 2006. Perempuan. Jakarta: Lentera Hati.

Nurhadi. 2006. Teori Perundangundangan. Prinsip-prinsip Legislasi, Hukum Perdata dan Hukum Pidana, terjemahan dari Jeremy Bentham The Theory of Legislation. Bandung: Penerbit Nusamedia \& Penerbit Nuansa.

Rama Stia Prasaja. 2014. Skripsi : Status Anak Akibat Pembatalan Perkawinan Hubungan Sedarah (Study Putusan No. 978/Pdt.G/2011/PA.Sda). Jember : FH- Univ. Jember

Richard Schoch. 2009. The Secret Of Happiness.Jakarta : Hikmah.

S. Soekanto \& Sri Mamudji. 2001. Penelitian Hukum Normatif; Suatu Tinjauan Singkat. Jakarta: PT. Raja Grafindo Persada.

Soerjono Wignjodipoere. 1988. Asasasas Hukum Adat. Jakarta : Gunung Agung.

\section{Jurnal}

Dyah Ochtorina Susanti. 2014. Syirkah Sebagai Model Investasi Berbasis Syari'ah (Kajian Ontologi). 
Rechtldee (Jurnal Hukum) Vol 9. No.1. Bangkalan: Fakultas Hukum Universitas Trunojoyo Madura.

Valerina JL. Kriekhoff. 2002. Analisis Kontent Dalam Penelitian Hukum : Suatu Telaah Awal. Era Hukum No, 6.

\section{Sumber Internet}

http://digilib.uinsby.ac.id/1720/4/Bab\%2 5201.pdf\&sa=U\&ved=0ahUKEwi wzLXfqpPQAhUBpo8KHVfvCn
UQFggXMAg\&usg=AFQjCNFuJ ECfkHvIX7EoW9HpQD3yousHg, diakses 5 November 2016

Zubaidillah, Nih Dia Kampung Nikah Siri di Rembang Kabupaten Pasuruan, http://radarbromo.jawapos.com/rea d2016/05/30/1291/nih-diakampung-nikah-siri-di-rembangkabupaten-pasuruan/1, artikel oleh Zubaidillah, 30 Mei 2016, diakses $5 \quad$ November 2016. 